\title{
Comparative Study on the Use of the Educational Resources of PeruEduca by Teachers from Arequipa and Moquegua
}

\author{
Anyela Bejarano, Steve Pareja and Marco Córdova \\ Universidad Católica de Santa María \\ Arequipa, Perú \\ Teresa Ramos-Quispe \\ Universidad Continental \\ Arequipa, Perú \\ Antonio Silva Sprock \\ Universidad Central de Venezuela \\ Caracas, Venezuela \\ Klinge Orlando Villalba-Condori \\ Universidad Nacional de San Agustín de Arequipa \\ Arequipa, Perú
}

\begin{abstract}
PeruEduca is an educational platform implemented by the Ministry of Education of Perú for providing free resources for teaching at different educational levels. This research presents the analysis of the use of PeruEduca in the teaching-learning process. This study began with a survey carried out with two groups of teachers belonging to the regions of Moquegua and Arequipa, using the criteria of mandatory Educational Quality Examination of the Ministry of Education, which is applied annually. The teachers are graduates of the master's degree course in the management of virtual learning environments offered by the Catholic University of Santa María. The analysis was carried out considering two aspects: digital competencies and the teaching-learning process. The results of this survey indicate that students from the Moquegua region are having better performances in their learning than students of the Arequipa region. This difference could be attributed to the extensive use of digital resources from the PeruEduca platform in the teaching-learning process. Thus, teachers must be sensitized at the local level to reflect on their pedagogical practices and incorporate methodological strategies in which they can use virtual environments in the development of their learning sessions.
\end{abstract}

Keywords: educational resources; open resources; virtual learning environment; PeruEduca; Arequipa; Moquegua 


\section{Introduction}

The education system of Peru needs to be reviewed because children can no longer be educated in the same way as they have always been. It is necessary to understand that the traditional forms of education have been a direct consequence of the industrial revolution and, consequently demanded a certain type of organization following the industrialized society in which division of labor, specialization and mass production are the main driving factors. However, we are now already in the $21^{\text {st }}$ century and we are living in the socalled information society or knowledge society, which has seen some notable changes in the educational and cultural transmission processes. In this sense, it is necessary to train students so that they can contribute to present society. However, there is a feeling that with the current educational system, the students are being prepared for a society of the past. In the new social space, there are no scenarios specifically designed for education, or if there are, these are very few. This is one of the tasks that must be done immediately, although it is not the only one (Echevarría, 2000).

New technologies, warns Silva (2011), are giving way to the emergence of new educational scenarios; meanwhile, traditional spaces are undergoing profound transformation and restructuring processes, hand in hand with the advent of virtual learning and communication environments (Arencibia, 2020). These virtual learning environments (VLE) emerge as particularly ideal scenarios for training, coaching, practice, and capacity building in the educational field. However, it is necessary to take into account the difference in the effective use of resources, the digital tools that teachers and students consider in the educational process, according to the different pedagogical and didactic models in which these environments are framed (Monereo \& Badia, 2013).

Along the same lines, Fernández and Vázquez (2017) explain three gaps that have prevented the total massification of new technologies. Firstly, there is the primary gap related to access (cost of equipment), which has prevented many schools from acquiring new equipment. The second refers to the user that allows, in theory, adequate management of these technologies, but which is not fully realized. Finally, the third is which separates schools from society. The first gap is almost overcome, mainly because acquisition costs have been considerably reduced. The second persists even though many of today's users live connected to the network or use it from their homes, schools, or workplaces. The third is the most serious of all since it involves two large institutions that have always had a reciprocal relationship throughout history, i.e., schools and society.

There are different proposals on what the profile of the $21^{\text {st }}$ century teacher should look like. In this regard, the United Nations Educational, Scientific and Cultural Organization (UNESCO) published a document called the ICT Competency Standards for Teachers (UNESCO, 2008) which was intended to be a guide for teacher training institutions, to contribute to the creation or revision of their training programs. For its part, the European Commission states that digital competence implies the critical and safe use of Information Technologies 
for work, leisure, and communication. To achieve this, it must rely on necessary ICT skills such as the use of computers to retrieve, assess, store, produce, present and exchange information, and to communicate and participate in collaborative networks over the Internet (European Union, 2006).

Within the Good Teaching Performance Framework, the Ministry of Education of Peru establishes that all teachers who carry out their pedagogical practice in Regular Basic Education (initial, primary and secondary levels) must develop teaching skills to achieve the results specified in performance 8 and 23, which refers to the use of technology and which allows them to recreate innovative methodologies to promote the development of a digital culture that will make it possible for students to learn more appropriate contentn in a better way (Ministerio de Educación, 2012). Facing the uncontrollable changes that society presents and the influence that technological means have on the mind, culture, and education of students, it becomes urgent to rethink pedagogical practices and the choice of these. A separate analysis is required on the theme of strategies and resources used to develop digital competencies, since they are the entire set of elements, tools, or procedures that teachers use, or can use, as support, complement, or help in their teaching tasks (Díaz, 1994). This concept highlights the usefulness of this "set of elements" that complements the teaching task (Salinas, 2011).

On the other hand, Corrales and Sierras (2002) define academic means and resources as the set of elements or instruments that aim to help trainers in their teaching task and also to facilitate students in the achievement of learning objectives. These resources are made up of all the digital strategies which are offered for free for non-commercial use by teachers and students for teaching, learning, and research (Miravalles, 2012).

However, Open Educational Resources (OER) are either in the public domain or have been published under an intellectual property license that allows them to be used, adapted and distributed free of charge, that is, anyone can consult them, reuse them and create new materials (Velázquez et al., 2014). This is how educational portals arise as tools to help teachers, since they simplify planning, facilitate the selection and publication of content and familiarize students with the tools and information management in the new media, which drives the teaching and learning process (Gros \& Contreras, 2006).

Educational portals appear as part of the interest of governments in extending their educational policies and bringing together the educational community in the same virtual space (Romero, 2010). Educational portals then become the gateway to a large amount of information and content that is strictly pedagogical, and that teachers and students can use without restriction. Such educational platforms can be regarded as an ecosystem for teaching and learning (Frango et al., 2013; Frango, Ochoa, Silva, Notargiacomo \& Hernández, 2011). Bedriñana (2005) defines an educational portal as any webspace that offers multiple services to the members of the educational community (teachers, students, managers, and families), such as information, data search tools, 
academic resources, tools for interpersonal communication, training, advice, entertainment, etc. In addition to being able to freely use it, it is important that the teacher can find resources suitable to his intention (Maldonado \& Pérez, 2018; Villalba-Condori et al, 2019; Yadav \& Berges, 2019; Pérez).

\section{Educational Portals}

There are nineteen educational portals in the Latin American Network of Educational Portals (RELPE). Eight of them require prior registration to access the resources. This is the case of PeruEduca, TiCrupive (Paraguay), Educa Panama, Educatrachos (Honduras), Educar Chile, Colombia Aprende, Portal do Profesor and Educar (Argentina). However, the remaining eleven portals do not require registration and these are Mundo Escolar (Venezuela), Uruguay Educa, Educando (Dominican Republic), Nicaragua Educa, the Secretaría de Educación Pública - SEP (Mexico), the Portal Educativo del Ministerio de Educación de Guatemala, Mi Portal (El Salvador), Educar (Ecuador), Cuba Educa, Educatico (Costa Rica) and Educa Bolivia. Another essential regional portal is the Latin American Federation of Learning Object Repositories (LAFLOR). This federation brings together more than 50,000 educational materials in Spanish, Portuguese and English. Another such portal is the World Federation of Repositories of Learning Objects (GLOBE) (Velázquez et al., 2014).

PeruEduca's closest precedents are the EDURED programs, which aimed to guarantee the connection of different urban schools to the network. Also outstanding is INFOESCUELA, a program aimed at developing activities in the field of robotics at the primary education level, which reached 400 public schools in 17 cities of the country. The third program was a pilot initiative in distance education approved in 1998 and launched only in 2000, whose purpose was to improve the coverage of primary education in rural areas, contribute to the universalization of the supply of quality basic education at the national level and expand the number of secondary schools in the rural and border areas (Balarin, 2013). Each of these programs was created during the government of Alberto Fujimori and they managed to improve the conditions and opportunities for the use of ICTs and the Internet.

After many years, the government of Alejandro Toledo created the Huascarán program, which consisted of the inclusion of ICTs in public educational institutions through the Pedagogical Innovation Classroom (AIP - Aula de Innovación Pedagógica). Its general objective was to expand the quality and coverage of education through the use of ICTs and promote higher levels of decentralization, democratization, and equity. Iit also covered the pre-school, primary and secondary levels in urban and rural areas of Peru, benefiting 2,527,045 students and 48,267 teachers (Ascarza, 2003).

The Huascarán project operated until the end of the Toledo Government, and in 2007 its functions were absorbed by the General Directorate of Educational Technologies (DIGETE), created during the government of Alan García (DS. No. 16-2007-ED). By 2016, as a result of a restructuring of the Ministry of Education (MINEDU), DIGETE became the Directorate of Technological Innovation in 
Education (DITE). PeruEduca was born as a portal in 2001 as part of the Huascarán Project, and in 2004, it became a full member of the Latin American Network of Educational Portals (RELPE). In 2011, it was rebranded as a digital learning system, after a total re-engineering. By 2015, PeruEduca had 715,000 registered users, of which 430,000 were teachers, and 200,000 were students. Likewise, 18 million visits were registered and through its virtual classrooms, 242 courses were held, serving more than 280,000 users.

The results of a 2013 survey (INEGI, 2013) confirmed that the $53 \%$ of educational institutions were using in PeruEduca and that it had a total of 513,987 users (373,383 teachers and 140,604 students). Currently, PeruEduca has progressively increased its pedagogical support for teachers and students. Through PeruEduca, users can find articles, forums, videoconferencing facilities, educational games, texts, simulators, computer graphics, audio resources, video resources, images and stories, which can be downloaded for free and used pedagogically in the classroom with students for better learning.

\section{Methodology}

This section describes the instruments, the study design, the data collection and the sample used in this study.

\subsection{Population}

This research was carried out at the Graduate School of the Catholic University of Santa María which, with teachers who had graduated from the master's in management of Virtual Learning Environments program. This university is located in the region of Arequipa in Peru. A total of 1,400 teachers were available to participate in this study. Five hundred of them were teachers from the Program Master 3.0 Scholarship for Arequipa teachers and 900 were teachers from the 600 Scholarship program for Moquegua teachers.

\subsection{Instruments}

The objective of this instrument was to measure the degree of 'Use of the PeruEduca' platform by teachers and students from Arequipa and Moquegua (two regions from Peru). This variable was further subdivided into two dimensions: teaching skills and pedagogical practices. The survey instrument is provided in Appendix 1. It is essential to point out that this instrument was first validated by a group of teachers (who were not part of the survey participants) before it went through another validation process by five experts. Some corrections were made after this process. Furthermore, the mean of the Aitken's validity factor was found to be 0.896 for these two dimensions. There was also a high degree of consistency among the different experts. For Cronbach's Alpha, the tool was reliable, since the coefficient is a value close to $1(0.840<1)$. Values higher than 0.7 normally indicate that the instrument is reliable.

\subsection{Study design and data collection}

The present research has a quantitative nature, of a similar descriptive type, and to carry it out, quantitative techniques were applied that allowed the selection and comparative analysis of data provided by the teachers from the 3.0 
Scholarship program from Arequipa and 600 Scholarship program from Moquegua. Teachers' e-mails were used to send them the survey link, which consisted of a form developed with the e-survey software (http://www.eencuesta.com). Once all the relevant data were gathered, they were tabulated for analysis and interpretation.

\subsection{Sample}

The sample for this study was 238 teachers which was divided into two groups: 165 teachers from Arequipa from the 3.0 Scholarship program, and 73 teachers from Moquegua from the 600 Scholarship program.

\section{Results}

The results were analysed using the SPSS statistical package, with which the value of the statistic and the p-value of contrast probability were calculated. We used the Kolgomorov-Smirnov test with Lilliefors' correction to verify if the data were typically distributed. According to the analysis of normality and comparing the levels of significance (the p-values), it can be seen that in the digital competences of teachers, there are parametric behaviors ( $p$-value is $0.200>0.005)$; therefore, it is homogeneous. In the other two cases, i.e., Teaching Practice and Use of PeruEduca, non-parametric behaviors are found, since their p-values are very low; in this case, Teaching Practice $(0.000<0.005)$ and Use of PeruEduca $(0.006<0.005)$. Once the normality test was performed, the criteria for the validation of the proposed hypotheses were determined.

As the normalization of the 'Use of PeruEduca' and 'Pedagogical Practice' dimensions were rejected, it was decided to apply non-parametric tests where the tests are done on the median of the distribution. The Mann-Whitney U test was used, which allowed the application of these criteria for two independent samples. This test is the non-parametric version of the Student "T" test, which is an appropriate one to apply to the 'Use of PeruEduca' and P'edagogical Practice' dimensions. Table 1 shows the results of the analysis of the variables grouped under the 'Use of PeruEduca', while Table 2 shows a comparison of the medians.

Table 1: Clustering variable - Use of PeruEduca

\begin{tabular}{|l|c|}
\hline Statistic & Use of PeruEduca \\
\hline Mann-Whitney U & 5182.500 \\
\hline Significance (2-tails) & 0.086 \\
\hline
\end{tabular}

According to the significance $(0.086>0.05)$, the 'Use of PeruEduca' in both regions (Arequipa and Moquegua) is similar.

Table 2: Comparison of medians

\begin{tabular}{|c|c|c|}
\hline Statistic & Arequipa use & Moquegua use \\
\hline $\mathrm{N}$ & 165 & 73 \\
\hline Median & 74.00 & 81.00 \\
\hline
\end{tabular}


Because it is non-parametric, the medians are compared. In Arequipa, this value is located is smaller because in this city the teachers do not yet recurrently use the platform either for their pedagogical practice or to develop their teaching skills while in Moquegua the results show a normal level of use. This is because these teachers have benefited from training in Information Technologies, as well as a process of intervention by the regional government of Moquegua. This has allowed teachers to take advantage of virtual resources and insert them in their pedagogical practice. Thus, they are better able to develop their teaching skills using educational platforms platform which the government has implemented for them. Table 3 shows the results of the analysis of the variables grouped under Pedagogical Practice (PP).

Table 3: Clustering variable - Pedagogical Practice

\begin{tabular}{|l|c|}
\hline Statistic & Pedagogical Practice \\
\hline Mann-Whitney U & 4947.000 \\
\hline Significance (2-tails) & 0.028 \\
\hline
\end{tabular}

Depending on the significance, the value is less than $0.05(0.028<0.05)$. Therefore, the use of PeruEduca for pedagogical practice is different in the regions of Arequipa and Moquegua. The comparison of medians can be seen in Table 4. In Arequipa, the median is smaller than Moquegua.

Table 4: Comparison of medians

\begin{tabular}{|c|c|c|}
\hline Statistic & Arequipa Practice & Moquegua Practice \\
\hline N & 165 & 73 \\
\hline Median & 50.0000 & 55.0000 \\
\hline
\end{tabular}

Next, the homoscedasticity of the sample has been verified using the Levene's test. This test indicates that the variances are equal. Therefore, the t-value for equal variances are chosen. It can be seen from Table 5 that the digital competences are similar $(0.93>0.05)$ for the teachers of both regions.

Table 5: Independent sample testing

\begin{tabular}{|c|c|c|c|c|c|c|c|c|c|c|}
\hline & & \multicolumn{2}{|c|}{ Levene test } & \multicolumn{7}{|c|}{ t-test for equality of means } \\
\hline & & \multirow[t]{2}{*}{$\mathrm{F}$} & \multirow[t]{2}{*}{ Sig. } & \multirow[t]{2}{*}{$t$} & \multirow[t]{2}{*}{ Df } & \multirow[t]{2}{*}{$\begin{array}{c}\text { Sig. } \\
\text { (2-tailed) }\end{array}$} & \multirow[t]{2}{*}{$\begin{array}{c}\text { Means } \\
\text { difference }\end{array}$} & \multirow[t]{2}{*}{$\begin{array}{l}\text { Standard } \\
\text { error } \\
\text { difference }\end{array}$} & \multicolumn{2}{|c|}{$\begin{array}{c}95 \% \\
\text { Confidence } \\
\text { interval of the } \\
\text { difference }\end{array}$} \\
\hline & & & & & & & & & Lower & Higher \\
\hline \multirow{2}{*}{$\begin{array}{c}\text { Digital } \\
\text { competence }\end{array}$} & $\begin{array}{c}\text { Equal } \\
\text { deviations } \\
\text { assumed }\end{array}$ & 2.84 & 0.093 & -0.85 & 236 & 0.39 & -1.23 & 1.45 & -4.08 & 1.62 \\
\hline & $\begin{array}{c}\text { Equal variances } \\
\text { not assumed }\end{array}$ & & & -0.80 & 120.40 & 0.25 & -1.23 & 1.54 & -4.27 & 1.81 \\
\hline
\end{tabular}




\section{Discussion}

The importance of an educational portal does not lie in the number of registered users but the quality of access, that is to say, how long users stay on the platform, how much resources they view/download, whether they publish content or propose improvements for student learning (RELPE, 2013). At this point, it is essential to note that all the portals that make up the Latin American Network of Educational Portals (RELPE) offer a large number of educational resources in various formats and allow the downloading of these resources without any restrictions. Teachers use these resources as a means to facilitate communication and access to information and to help in their teaching practice. However, these online educational portals are not a panacea and an all-inclusive solution in themselves as it is often seen that they do not encourage in-depth learning as many students tend to remain passive and receptive only. Currently, the way in which educational resources are provided in these platforms does not allow for new ways of interacting with information, but rather persists in responsive and traditional behaviors. Improving pedagogical practices and making good use of these resources require developing educational strategies to acquire multiple skills, managing life-long learning, designing meaningful learning experiences, and using ICT reflectively and critically.

\subsection{Digital Competences}

Regarding the dimension related to Digital Competences in Teachers, UNESCO defines digital competencies as a spectrum of competencies that facilitate the use of digital devices, communication applications, and networks to access, and better manage information. From a pedagogical point of view, UNESCO classifies these competencies at three levels, from the simplest to the most complex: Level of Integration, Level of Reorientation and Level of Evolution. In this regard, UNESCO (2016) points out that these competencies enable the creation and exchange of digital content, communication, and collaboration, as well as problem-solving for productive and creative development in life, work, and social activities in general.

In this sense, the vast majority of teachers in both programs (3.0 Scholarship and 600 Scholarship) have shown skills to search, download or save the appropriate resources (videos, audios, simulators, computer graphics, learning objects, texts, animations, educational games, etc.) that they find in PeruEduca. This is known as content healing. Due to the enormous amount of resources that are available today on the Internet, it is necessary for teachers to have these set of skills. However, this is not sufficient to affirm that the levels of digital competencies of teachers in both regions are ideal, since taking as a reference what UNESCO has proposed we can say that teachers in both programs are more at the Level of Integration, that is, teachers are making use of ICTs for the transmission and storage of information (Martí, 2003). This means that teachers can use ICT services, but they only do so only for reference or to show content in their learning sessions. Still, they do not modify or contextualize this content to their reality. Most of them are still not generating any new content. Thus, the present investigation concludes that the use of educational resources in PeruEduca in the Digital Competences dimension is similar for the teachers from both regions. 


\subsection{Participation of teachers}

A majority of teachers have participated in virtual courses on the PeruEduca platform. However, they have very little experience with the various synchronous and asynchronous communication services (forums, blogs, chats, wikis, groups, educational communities) which are available on the platform. Digital competencies are a set of skills, functions, and abilities necessary for the use of information and communication technologies and are evidenced in the strategic mastery of five major capacities associated with the different dimensions of digital competency: access, adoption, adaptation, appropriation, and innovation (Díaz and Picón, 2016). Teachers in both programs have only reached the first two capacities (access and adoption) since they do not experience any difficulty in accessing and adopting these resources in their daily activities. However, when it comes to using these supports in their pedagogical work through modifying, contextualizing or creating new resources, they find it very difficult to do so. Digital competencies in teachers seek to enrich their pedagogical work and contribute to student learning as long as they are used strategically and creatively. Thus, teachers must have an adequate level of knowledge and an excellent attitude towards the adoption of new technologies.

\subsection{Pedagogical practice dimension}

The teaching work is analyzed to see whether it has the capacity to support meaningful learning and the integral development of students. This can be done through the creation of exercises and activities which are full of meaning for those who participate in them. The recognition of disciplinary or environmental problems, the generation of experiences that promote particular relations with the identified problems, the promotion of reflection and critical thinking and the integral assessment of learning are also important elements of good pedagogical practices. Thus, in both programs, the tendency is to use these resources regularly (audios, simulators, computer graphics, learning objects, animations, educational games, etc.) with a few exceptions, such as, the videos and texts of the Ministry of Education (MED). Consequently, these results confirm that teachers in both programs are at the Integration Level, that is, they use ICT as a tool to optimize content presentation, communication, and information transmission. The use of educational resources in PeruEduca in the practical pedagogical dimension was found to be different for teachers from both regions.

\section{Conclusions}

The digital competencies and pedagogical practice of teachers in two different regions in Peru were analysed through a survey on the way they use the PeruEduca educational platform. We found that Moquegua teacher make more frequent use of the educational resources in PeruEduca than Arequipa teachers. Educational portals such as PeruEduca are not in themselves a guarantee of improvement in student learning. Instead, they should be seen as tools whose potential has not yet been fully exploited. Teachers must be sensitized at the local level to reflect on their pedagogical practices and incorporate methodological strategies in which they can use virtual environments in their learning sessions. Finally, more dissemination must be made at the level of educational institutions to inform them about the resources that available on PeruEduca so that teachers and students can use it to its full extent. 


\section{References}

Arencibia, Y., Cawanga, I., Deco, C., Bender, C., Avello-Martínez, R., \& Villalba-Condori, K. (2020). Developing computational thinking with a module of solved problems. Computer Applications in Engineering Education, 2020. https://doi.org/10.1002/cae.22214

Ascarza, A. (2003). Las nuevas tecnologías de información y comunicación (NTIC) en el diseño de proyectos nacionales para la modernización de la educación iberoamericana: bases para el programa Huascarán [The new information and communication technologies (NTIC) in the design of national projects for the modernization of Ibero-American education: bases for the Huascarán program. Management in the third millennium]. Gestión en el tercer milenio, 5(10), 13-17.

Balarín, M. (2013). ICT policies in Latin American education systems: Case of Peru. Buenos Aires: UNICEF.

Bedriñana, A. (2005). Técnicas e indicadores para la evaluación de portales educativos en Internet [Techniques and indicators for the evaluation of educational portals on the Internet]. Gestion en el Tercer Milenio, 7(14), 81-87.

Corrales, M., \& Sierras, M. (2002). Design of educational resources and resources. Málaga: Antequera.

Díaz, H., \& Picón, C. (2016). Teaching management in Peru. Critical challenges and possibilities of response. Lima: Fundación telefónica.

Díaz, J. (1994). Resources and teaching materials in physical education. Barcelona: INDE.

Echeverría, J. (2000). Educación y tecnologías telemáticas [Education and telematic technologies]. Revista Iberoamericana de Educación, 24, 17-36.

Fernández, M., \& Vázquez, S. (2017). The long and complex march of the clip to the click: school and teachers in the new digital environment. Barcelona, Ariel: Fundación Telefónica.

Frango Silveira, I., Ochoa, X., Silva Sprock, A., Notargiacomo, P., \& Hernández, Y. (2011). Towards New Computational Architectures for Mass-Collaborative Open Educational Resources. International Journal of Digital Information and Wireless Communications (IJDIWC), 1(2), 489-503.

Frango Silveira, I., Ochoa, X., Cuadros-Vargas, A., Pérez Casas, A., Casali, A., Ortega, A., Silva Sprock, A., Henrique Alves, C., Deco, C., Cuadros-Vargas, E., Knihs, E., Parra, G., Muñoz-Arteaga, J., Gomes dos Santos, J., Broisin, J., Omar, N., Motz, R., Rodés, V., \& Hernández, Y. (2013). A Digital Ecosystem for the Collaborative Production of Open Textbooks: The LATIn. Methodology. Journal of Information Technology Education: Research (JITE: Research), 12, 225-249.

Gros, B., \& Contreras, D. (2006). La alfabetización digital y el desarrollo de competencias ciudadanas [Digital literacy and the development of citizen skills]. Revista Iberoamericana de educación, 42, 103-125.

Martí, E. (2003). Representing the world externally: child acquisition of external systems of representation. Madrid: Machado.

Ministerio de Educación. (2012). Framework of good teaching performance. Lima: MINEDU.

Miravalles, M. P. T. (2012). Recursos Educativos en Abierto: evolución y modelos [Open Educational Resources: evolution and models]. Foro de Educación, 10(14), 191-205.

Monereo, C., \& Badia, A. (2013). Aprendizaje estratégico y tecnologías de la información y la comunicación: Una revisión crítica [Strategic Learning and Information and Communication Technologies: A Critical Review]. TESI, 14(2), 15-41.

Pérez-Álvarez, R., Maldonado-Mahauad, J., \& Pérez-Sanagustín, M. (2018) Tools to Support Self-Regulated Learning in Online Environments: Literature Review. In: Pammer-Schindler V., Pérez-Sanagustín M., Drachsler H., Elferink R., Scheffel M. (eds) Lifelong Technology-Enhanced Learning. EC-TEL 2018. Lecture Notes in 
Computer Science, vol. 11082. Springer, Cham. https://doi.org/10.1007/978-3319-98572-5_2.

European Union. (2006). Recommendation of the european parliament and of the council. Retrieved from:

https://eurlex.europa.eu/LexUriServ/LexUriServ.do?uri=OJ:L:2006:394:0010:0018:en:PDF

Red Latinoamericana Portales Educativos - RELPE. (2013). La nueva agenda de los portales educativos de América Latina: Casos de Argentina, Chile y Perú [The new agenda of educational portals in Latin America: Cases of Argentina, Chile and Peru]. Retrieved from http://www2.congreso.gob.pe/sicr/cendocbib/con4_uibd.nsf/F65CA50893757 80F05257E3600782557/\$FILE/15-La-nueva-agenda-de-los-portales-educativosde-Am\%C3\%A9rica-latina-casos-de-Argentina-Chile-y-Per\%C3\%BA.pdf

Romero, D. (2010). Experiencia en la producción y oferta de contenidos educativos digitales en Medellín, Colombia. El caso del portal educativo de Medellín Digital [Experience in the production and supply of digital educational content in Medellín, Colombia. The case of the Medellín Digital educational portal]. Comunicación, 27, 35-50.

Salinas, M. I. (2011). Entornos virtuales de aprendizaje en la escuela: tipos, modelo didáctico y rol del docente [Virtual learning environments at school: types, didactic model and role of the teacher]. Retrieved from: http://eduteka.icesi.edu.co/gp/upload/Educaci\%C3\%B3n\%20EVA.pdf.

Silva, J. (2011). Design and moderation of Virtual Learning Environments. Barcelona: Editorial UOC.

Sistema Nacional de Información Estadística y Geográfica - INEGI. (2013). Encuesta sobre Tecnologías de la información y las comunicaciones [Information and Communication Technologies Survey]. Retrieved from: https://www.inegi.org.mx/programas/entic/2013/

Organización de las Naciones Unidas para la Educación, la Ciencia y Cultura UNESCO. (2008). ICT competency standards for teachers. London: UNESCO.

Organización de las Naciones Unidas para la Educación, la Ciencia y Cultura UNESCO. (2016). Competences and Standards from the Pedagogical Dimension. Cali: UNESCO.

Velázquez Amador, C., Álvarez Rodríguez, F., Muñoz Arteaga, J., Cardona Salas, J., Silva Sprock, A., Hernández, Y., \& Cechinel, C. (2014). Un Estudio de la Satisfacción Obtenida con el Uso de Objetos de Aprendizaje [A Study of Satisfaction Obtained with the Use of Learning Objects], IX Latin American Conference on Learning Objects and Technologies for Learning (LACLO2014), Universidad Nacional de Colombia. Manizales, Colombia.

Villalba-Condori, K., Deco, C., Oliva Córdova, L. Castro Cuba Sayco, S., Bender, C., \& Silva Sprock, A. (2019). A Methodology to Assign Educational Resources with Metadata Based on the Purpose of Learning, 2019 XIV Latin American Conference on Learning Technologies (LACLO), San Jose Del Cabo, Mexico, 2019, pp. 221-225. https://doi.org/10.1109/LACLO49268.2019.00045

Yadav, A., Berges, M. (2019). Computer Science Pedagogical Content Knowledge: Characterizing Teacher Performance, ACM Transactions on Computing Education, 19(3). https://doi.org/10.1145/3303770 


\section{Appendix 1}

\section{SURVEY}

\section{USE OF PERUVIAN EDUCATIONAL RESOURCES}

The following survey has been prepared for research purposes, so please answer truthfully, as the information we wish to obtain is very important for a large study that will benefit teachers. The survey is anonymous and we guarantee absolute confidentiality in the processing and dissemination of the results.

Thank you very much for your collaboration.

Universidad Católica de Santa María

Graduate School

\section{GENERAL DATA}

\section{Region}
a. Arequipa
b. Moquegua

\section{Sex}
a. Male
b. Female

\section{Age}

a. Less than 25 years old

b. Between 25 and 30 years

c. Between 31 and 35 years old

d. Between 36 and 40 years old

e. Between 41 and 45 years old

f. Between 46 and 50 years old

g. Between 51 and 55 years old

h. Between 56 and 60 years old

i. More than 61 years old

\section{EBR level \\ a. Initial \\ b. Primary \\ c. Secondary}

\section{UGEL}

a. UGEL North

b. UGEL South

c. UGEL La Unión

d. UGEL Castilla

e. UGEL Camaná

f. UGEL Caravelí

g. UGEL Condesuyos 


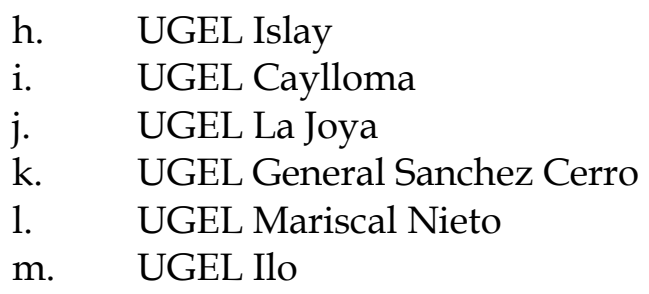

\section{Scope of your EI}
a. Urban
b. Rural

7. Time of service

a. Less than 5 years

b. From 5 to 10 years

c. From 11 to 15 years old

d. From 16 to 20 years old

e. More than 20 years

f. Nothing

\section{Area of expertise}

a. Initial

b. Primary

c. Communication

d. Mathematics

e. CTA

f. ER

g. $\mathrm{EF}$

h. EPT

i. Art and culture

j. Social Sciences

k. Others

\section{Teacher's Scale}

a. I

b. II

c. III

d. IV

e. $\mathrm{V}$

f. VI

10. Employment status

a. Named

b. Hired

11. Scholarship Promotion

a. First promotion Scholarship 600 (entry 2015)

b. Second promotion Scholarship 600 (entry 2016)

c. First promotion Scholarship 3.0 (entry 2016)

d. Second promotion Scholarship 3.0 (entry 2017) 


\section{ON THE USE OF THE PERUVIAN PLATFORM}

12. DO YOU KNOW THE PERUVIAN PLATFORM?
a. Yes
b. No

\section{ARE YOU REGISTERED IN PERUVIAN?}
a. Yes
b. No

\section{HOW OFTEN DO YOU ACCESS PERUEDUCA?}
a. Once or twice a week
b. Internally
c. Every day
d. Never

15. Indicate on the scale how often you perform the following actions (where 0 is none, and 5 is very often)

15A. DO YOU KNOW HOW TO SEARCH FOR THE EDUCATIONAL RESOURCES THAT PERUEDUCA OFFERS?

\begin{tabular}{|l|l|l|l|l|l|}
\hline 0 & 1 & 2 & 3 & 4 & 5 \\
\hline
\end{tabular}

15B. DO YOU EASILY FIND RESOURCES TO WORK IN YOUR AREA OR LEVEL?

\begin{tabular}{|l|l|l|l|l|l|}
\hline 0 & 1 & 2 & 3 & 4 & 5 \\
\hline
\end{tabular}

16. HOW OFTEN DO YOU USE THESE PERUVIAN SERVICES AND RESOURCES?

\begin{tabular}{|c|c|c|c|c|c|c|c|}
\hline No. & Service/Resource & $\mathbf{0}$ & $\mathbf{1}$ & $\mathbf{2}$ & $\mathbf{3}$ & $\mathbf{4}$ & $\mathbf{5}$ \\
\hline $16 \mathrm{~A}$ & Animations & & & & & & \\
\hline $16 \mathrm{~B}$ & Audios & & & & & & \\
\hline $16 \mathrm{C}$ & Fascicles & & & & & & \\
\hline $16 \mathrm{D}$ & Infographics & & & & & & \\
\hline $16 \mathrm{E}$ & Games & & & & & & \\
\hline $16 \mathrm{~F}$ & Books & & & & & & \\
\hline $16 \mathrm{G}$ & Modules & & & & & & \\
\hline $16 \mathrm{H}$ & Learning Objects & & & & & & \\
\hline
\end{tabular}




\begin{tabular}{|c|c|c|c|c|c|c|l|}
\hline $16 \mathrm{I}$ & Stories & & & & & & \\
\hline $16 \mathrm{~J}$ & Simulators & & & & & & \\
\hline $16 \mathrm{~K}$ & Recommended sites & & & & & & \\
\hline $16 \mathrm{~L}$ & Software & & & & & & \\
\hline $16 \mathrm{M}$ & Videos & & & & & & \\
\hline $16 \mathrm{~N}$ & MED texts & & & & & & \\
\hline
\end{tabular}

17. Indicate on the scale how often you perform the following actions (where 0 is none, and 5 is very often)

17A. DO YOU PROMOTE THE USE OF THESE RESOURCES AND SERVICES WITH YOUR STUDENTS?

\begin{tabular}{|l|l|l|l|l|l|}
\hline 0 & 1 & 2 & 3 & 4 & 5 \\
\hline
\end{tabular}

17B. HAVE THE RESOURCES AND SERVICES PERUEDUCA OFFERS HELPED YOU IN YOUR PEDAGOGICAL WORK?

\begin{tabular}{|l|l|l|l|l|l|}
\hline 0 & 1 & 2 & 3 & 4 & 5 \\
\hline
\end{tabular}

17C. DO YOU STORE IN AN ORGANIZED WAY THE PERUVIAN RESOURCES YOU ARE INTERESTED IN IN YOUR COMPUTER?

\begin{tabular}{|l|l|l|l|l|l|}
\hline 0 & 1 & 2 & 3 & 4 & 5 \\
\hline
\end{tabular}

17D. DO YOU PLAN YOUR LEARNING SESSION TAKING INTO ACCOUNT THE EDUCATIONAL RESOURCES DOWNLOADED FROM PERUVIAN THAT YOU STORED ON YOUR COMPUTER?

\begin{tabular}{|l|l|l|l|l|l|}
\hline 0 & 1 & 2 & 3 & 4 & 5 \\
\hline
\end{tabular}

17E. HAVE YOU PARTICIPATED IN ANY COURSE PROMOTED BY PERUEDUCA?

\begin{tabular}{|l|l|l|l|l|l|}
\hline 0 & 1 & 2 & 3 & 4 & 5 \\
\hline
\end{tabular}

17F. DO YOU USE PERUEDUCA'S BLOG TO PUBLISH YOUR EXPERIENCES IN THE CLASSROOM?

\begin{tabular}{|l|l|l|l|l|l|}
\hline 0 & 1 & 2 & 3 & 4 & 5 \\
\hline
\end{tabular}


17G. HAVE YOU CREATED OR PARTICIPATED IN A FORUM IN PERUEDUCA?

\begin{tabular}{|l|l|l|l|l|l|}
\hline 0 & 1 & 2 & 3 & 4 & 5 \\
\hline
\end{tabular}

17H. HAVE YOU CREATED OR PARTICIPATED IN A GROUP IN PERU?

\begin{tabular}{|l|l|l|l|l|l|}
\hline 0 & 1 & 2 & 3 & 4 & 5 \\
\hline
\end{tabular}

17I. DO YOU PARTICIPATE IN ANY PERUVIAN VIRTUAL COMMUNITY?

\begin{tabular}{|l|l|l|l|l|l|}
\hline 0 & 1 & 2 & 3 & 4 & 5 \\
\hline
\end{tabular}

17J. WOULD YOU RECOMMEND THE USE OF PERUEDUCA TO YOUR COLLEAGUES?

\begin{tabular}{|l|l|l|l|l|l|}
\hline 0 & 1 & 2 & 3 & 4 & 5 \\
\hline
\end{tabular}

